being more than one and having attained their majorities and not being incapacitated, to call for the distribution of his or their share or shares in the trust even though the settlor required distribution at a later age but did not provide for a gift over in the event of the prior death of the beneficiary or beneficiaries.

Trust duty is payable in the sum of $\$ 50.00$ on each trust instrument instead of stamp duty. Beneficiaries who are treated as non-residents for exchange control purposes are exempted from income taxes and other similar taxes on trust distributions. Where all of the beneficiaries of a trust are so treated, the trust instrument and other trust documents described in s. 93 will be exempt from stamp duty unless the trust property includes land in the Bahamas or the trust carries on a business or trade in the Bahamas.

Trust instruments and certain other trust documents are exempt from registration under the Registration of Records Act. The Exchange Control Regulations Act shall not apply to any settlor, grantor, donor or beneficiary who is treated as non-resident for exchange control purposes. The ECRA, except where otherwise expressly provided, applies to trusts, including executorship, constituted or created either before or after the commencement of the Trustee Act.

The Act helps to move the Bahamas to the cutting edge of innovative international trust legislation. It dramatically improves the image and reputation of the country as an important international financial centre and is another important reaffirmation of the country's interest in and commitment to responsibility, clean money and good trust business.

\title{
Comment
}

\section{Pension problems: who owes whom?}

\section{by John A Franks}

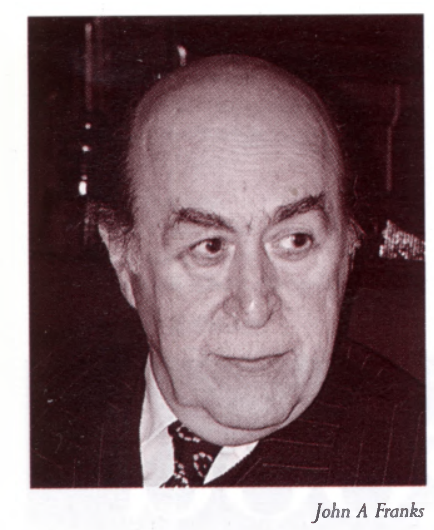

\section{M} uch has been made in the media by the present government of the alleged mis-selling of private pension schemes to individuals.

The problem arises because there may be a shortfall in the value and, therefore, the ultimate return which individuals had been led to expect. If so, loss can be measured in the difference in value so long as what is now the entitlement is less. The cause of the shortfall in this context appears to be twofold:

(1) the way charges for selling and managing the policy and the funds it represents were deducted from the premiums at the outset. The policy earnings, particularly in the first years, were lowered and this would mean early surrender values were depressed. It is said that this should have been explained;

(2) in many cases, the fact that the employee who committed to a staff pension scheme may have been disadvantaged when he took out a private pension in place of an occupational pension because of the loss of the employer's contribution (which would not be made to the individual's personal policy scheme) and the employee could no longer rely on the employer's legal duty to subvent the staff fund if the pension fund was inadequate.

However, there are other considerations of which account should be taken. There is the cost of portability of the rights to the corporate-funded pension. The individual scheme is wholly outwith the control of the employer and the company pension fund trustees. Moreover, there are no 'Maxwell-type' risks where the pension fund may be raided or particular assets alienated or hypothecated. Even to this day, 'stock lending' by pension fund trustees has not been outlawed. Also, where the pension fund has surplus value, this can be tapped by the employer taking a contribution holiday. With individual schemes, growth is likely to benefit the pensioner. For individuals who switch to a personal scheme, there is, therefore, not only a greater feeling of security, but no hassle over transfer values to be passed from the fund of the old employer to that of the new employer. Where an employer no longer makes a contribution, this may well be taken into account in dealing with the employee's emoluments at review in some other way.

Another factor is 'mis-selling' on the part of the government in regard to its treatment of individuals over SERPS. The market for switching to private pensions was stimulated by the desire of government to be relieved of the future unfunded liabilities for state additional pension schemes. A premium was offered by government as a contribution to private schemes to encourage change by individuals. If the current government campaign has any validity, the government was at fault not to issue at least 'health warnings' against the mischiefs which are said to justify claims for mis-selling being made. Will the government accept liability for mis-selling pensioners back into SERPS or will they resile from the reduction in widows' pensions?

At the same time as releasing what might be regarded as divisive allegations to thousands, the government is taking care to withdraw the Legal Aid and Advice Scheme. This will mean 
that legal help is not freely available to advise potential claimants as to whether or not they may have some right to compensation because of the responsibility that government had for the situation. This might be a matter for the law courts or, indeed, the European Court of Human Rights.

Beyond all of this is the situation created by the drastic reduction to accruals to insurance companies and pension funds through fiscal change. This is causing diminution in values which aggravate the situation. In 1987 the Chancellor introduced the so-called 'windfall tax' designed to recover some gains in respect of privatisation. The stockholders who ultimately were disadvantaged in the main are not individuals but the pension funds and insurance companies. As this did not produce any direct impact on individuals in terms of their net spendable cash, the effect on the future resources for pension payments did not produce any serious public reaction. The government went unscathed and so in 1998 advance corporation tax (ACT) rules were changed. Cash recovery by pension funds and insurance companies was halved and will be further reduced. What this does is to make it certain that the private pension returns are badly affected. If it were not for these tax measures even the worst 'mis-sold' schemes would have been likely to produce a much better result compared to those who continued to contribute to SERPS.

As was mentioned, it was said to be a great advantage of company schemes that if there was an actuarial shortfall in the pension fund, the employer paid. More employers will have to subvent the difference over the years, because of this unwelcome effect of government action over windfall tax and withdrawal of ACT credits. However, it should not be forgotten that any such subvention payment by the employer will be a charge against profits before tax - so long as the business is still profitable. No such allowance is being made to individual taxpayers who are not being permitted such a concession against their personal tax liability if there is a shortfall.
It is submitted that any claims for the alleged 'mis-selling' should take account of the following factors.

(1) Government actively promoted switching from SERPS and supported the principle of individual 'top-up pensions' without adequate guidance being given, i.e. no 'health warnings' or adequate minimum-term stipulations.

(2) New tax changes created an unfavourable regime for the funds of individual pension holders, quite apart from the government policy on reducing interest rates.

(3) The old SERPS opt-out premium is not being supplemented as it should be because of the fundamental change in fiscal arrangements, since funds are losing the right to recover the tax deducted from dividends, which seriously reduces yields.

(4) Corporate pension funds commonly disadvantage employees who change employment and may even penalise them in practice.

(5) If surplus funds do accrue these uplift individual pension benefit, but, in corporate pension funds, surplus funds are liable to be tapped by the employer.

(6) Unlike corporate pension funds, there is at present no subvention tax concession for individual taxpayers.

It is perfectly true that insurance companies and their representatives have been successfully pilloried by the government and are accepting liability. None of this should divert attention from the question as to what are the responsibilities of government and what it would be fair for the government to be doing in these circumstances.

John A Franks

Chethams, London

\section{What makes a good lawyer an expert?}

\section{Legal information as it happens}

